\title{
ANALYSIS AND DEVELOPMENT POSSIBILITIES OF BUSINESS INCUBATORS IN LATVIA
}

\author{
Iluta Arbidāne \\ Rezekne Academy of Technologies, Latvia \\ Madara Tarasova \\ The Rural Support Service, Latvia
}

\begin{abstract}
The nature of business incubators and their historical development in the world and in Latvia, the role in the global and Latvia's economy, the requirements set by the Investment and Development Agency of Latvia (LIAA) for the operators and enterprises of business incubators within the framework of the activity "Business Incubators" (implemented within the project "Development of Business Incubators in Latvia" co-funded by the European Regional Development Fund), as well as the results achieved by the business incubators and enterprises, and their future perspectives are covered in the research. The aim of the study is to explore and analyse the implementation and performance of the LIAA's activity „Business incubators" in Latvia. The main issues analysed in the paper are the implementation conditions, the results, and analysis of the activity "Business Incubators" administered by the LIAA, as well as its effect upon the business activity in Latvia. Based on the obtained results, the authors conclude that the continuation of the business incubators' operation is a precondition for development of innovative business and growth of the economy of Latvia.
\end{abstract}

Keywords: business incubator, development, enterprises, growth, possibilities, services.

\section{Introduction}

Business support instruments are mainly adjusted to the specifics of a particular region, though the basic principles are the same. Mostly, the support instruments are applied in the form of a state aid to enhance employment, exports, tax revenues, and overall development. One of the most common business support instruments is business incubators, which are primarily established to support new enterprises from their foundation until stabilization and ability to develop independently (Markus, 2010). The origins of business incubators in Latvia are quite recent, as it is in other Eastern and Central European countries, where the economies have relatively recently transferred to the conditions of market economy.

The insufficient number of viable, competitive, and economically active enterprises that enhance economic growth and provide a sufficient number of jobs could be marked as the main reason for establishing business incubators. In addition, Latvia is characterized by an uneven distribution of the economic 
activity on a regional basis. However, facilitating the establishment of the startup businesses seems to be an insufficient measure to guarantee sustainable development; to ensure increase in competitiveness, so that the newly established companies are viable. To help the new companies develop effectively, increase sales and, consequently, improve the well-being of the state, the Latvian Investment and Development Agency (hereinafter - LIAA) launched the activity „Business incubators” co-funded by the European Regional Development Fund (hereinafter - ERDF) in 2009. Basically, business incubators (hereinafter-BI) are structural units established to enhance the national and regional economic and social development.

The study aims to explore and analyse the implementation and performance of the LIAA's activity „Business incubators” in Latvia.

The object of the research is the business incubators and their development possibilities. The following methods have been used in the research:

1. Monographic or descriptive method to characterise the nature of BI, the LIAA's activity „Business incubators” co-funded by ERDF, and the BI future development perspectives in Latvia;

2. The method of statistical analysis to describe and analyse the process and the results of the LIAA's activity „Business incubators” during the period 2009-2013.

\section{Economic interpretation of the concept of business incubators}

The formal concept of a BI originated in 1959, when Joseph Mancuso opened the industrial centre in Batavia, New York. The founder of the first incubator created a new structure under the circumstances of the post-war economy, when many manufacturing companies were closed, the economic restructuring had to take place, and unemployment increased. In the 1980s, the concept of BI was developed emphasizing the fact that the structures were established for a successful business start-up and initial development phase (Abeltina, 2008).

The researchers emphasize that insufficient business performance and development depend basically on a company's manager, his/her knowledge and abilities. Many businesses fail because they have a weak management with minor knowledge (Jennings et al., 1997). In research, the economists (Stonehous et al., 2007) point out that the company's competitiveness is one of the most important factors affecting the SMEs performance and growth. Experience of economic development worldwide has demonstrated that competitiveness is affected by many different factors. In the economic theory, the capital investments and infrastructure had been considered as key factors. In 
latter stages, the economists believed that redirecting the resources to the „right” sectors and the ,right” companies in the particular sector was the most important challenge. By development of the economic science, the researchers broadened the range of issues under consideration by a number of factors: human and social capital, progress of technologies and innovation, business relationship with environment, character of demand, diversification of products and markets, etc. Nowadays, the economists and entrepreneurs, altogether, support the opinion that all the factors affecting competitiveness are interrelated and, therefore, shall be evaluated in the overall context. The companies and the countries that have resources to achieve the necessary level of productivity have a competitive advantage (Kassalis, 2010). Lack of the resources impedes the innovation in the small and medium-sized companies; in addition, SMEs face a number of obstacles and more extensive uncertainty than the large enterprises. The research data point out that the level of innovation in SMEs depends on the company's financial and human resources (Wang et al., 1993). Whereas, Todtling and Kaufman (2001) indicate that these problems can be solved by integration of enterprises in networks, innovation systems, and by reliance on the external partners. In many SMEs, insufficient attention is paid to the staff training; some experts believe that the government should be involved in their education. The researchers have pointed out that the innovation raises the competitiveness, increases the number of jobs, and makes the region wealthier (McDonald et al., 2007).

The main function of a business incubator is to enhance the establishment of new companies offering up-to-date information on legislation and other topics, consulting on marketing, management, financial management, accounting, and other issues important for the entrepreneur's activity. For many years, the incubators have been joined into the networks. The networks are used to share the experiences and the best-practice examples, thus promoting new methods. In Europe, there is a well-established network - European Business Centre - which links together more than 250 business and innovation centres across Europe (Join us, 2015). In total, there are more than 9000 continuously operating incubators in the world. In Latvia, the BIs represent a relatively new instrument introduced by the assistance of the Ministry of Economics in 2007.

\section{Characteristics, results, and analysis of activity „Business incubators” implemented by the LIAA}

In Latvia, the activity "Business incubators" (the amendment of the Program „Entrepreneurship and Innovation”, Priority 2.3. „Improvement of Business Activity and Competitiveness”, Measure 2.3.2. „Business Infrastructure and Improvements to Equipment”, Activity 2.3.2.1. „Business 
incubators" of the programming period 2007- 2013) was launched in two stages. The first stage took place from 2009 to summer 2014. In 2014, the new transition period tender for the BI operators was announced; the winners of the tender were able to provide the incubation services until 31 October 2015 (Initial Evaluation by the Ministry of Economics, 2015) with extension until 31 December 2015, thus ensuring the continuity of the business incubation services for the new entrepreneurs. In 2009, the contracts with the business incubator operators were signed at different times; hence, the duration of the contracts varied and, in 2014, provision of the incubation services was interrupted at different time of the year from April to October. Since in all cases, the services were provided for less than a year, the evaluation does not include assessment of the entrepreneurs' 2014 annual reports. In 2015, the contracts were signed at different times; hence the evaluation does not include assessment of the businesses incubated in 2015, because at the time the evaluation was carried out, some of the BI still worked implementing the contracts (Initial Evaluation by the Ministry of Economics, 2015).

According to the legislation of the Republic of Latvia, the activity „Business incubators" was introduced with the aim to promote establishment and development of new, viable, and competitive businesses in Latvia's regions, providing them with the necessary business environment and advisory services. The implementation of the activity was focused on the resolving of challenges of the unbalanced market development by stimulating the increase of number of enterprises and business activities in Latvia's regions. It should be noted that the legislation reflected certain restriction which defined that the aid was not provided for the entrepreneurs of Riga city, Riga district, and Jurmala city. The most economically effective BI service providers were selected in accordance with the Public Procurement procedure - altogether 8 BI operators in Latvia.

The activity of BI in Latvia began its growth after the government allocated funds to support the BI-2.28 million EUR in 2007 and the same amount in 2008. In 2007, 11 innovation centres and the BI projects received support of the Ministry of Economics (Markus, 2010). In order to enhance establishment and development of micro, small and medium-sized businesses, since 2009, the LIAA has implemented the project „Development of Business Incubators in Latvia" co-funded by ERDF. The total available public funds for the activity was 28.74 million EUR, including the 24.43 million EUR (85\%) funding by the ERDF and 34.31 million EUR (15\%) by the state budget. Support for the new businesses was allocated to last until 31 October 2014.

The data (Table 1) show that all the available funding was divided proportionally among the planning regions, providing $20 \%$ of the total amount to each planning region. Whereas, $10 \%$ of the available funding was allocated to the Riga planning region, except Riga city, Jurmala city, and Riga district, and 
$10 \%$ - to the creative industries BI in Riga. Assessing the share of the funding per inhabitant of the region, it is evident that, in the regions with less population, the funding is consequently bigger. The least amount of funding per inhabitant was received by the Latgale Planning Region - 17.80 EUR per inhabitant, which is 1.44 times less than the funding per inhabitant received by the Vidzeme Planning Region. The authors' opinion is that the public funding was divided incorrectly by allocating the same amount of funding to all regions, regardless of the peculiarities and specific factors, such as the number of population in the region, unemployment rate, economic growth, business activity, availability of infrastructure, the number of students, and other, which certainly differ in each region.

Table 1 Funding available for the planning regions of Latvia to implement the activity "Business Incubators" at the initial stage in 2009 (by the authors)

\begin{tabular}{|l|c|c|c|c|}
\hline \multicolumn{1}{|c|}{ Planning region } & $\begin{array}{c}\text { Available } \\
\text { funding, } \\
\text { EUR }\end{array}$ & $\begin{array}{c}\text { Available } \\
\text { funding, } \\
\text { \% }\end{array}$ & $\begin{array}{c}\text { Number of } \\
\text { population, } \\
\text { beginning } \\
\text { of 2009 }\end{array}$ & $\begin{array}{c}\text { Available } \\
\text { funding, } \\
\text { EUR per 1 } \\
\text { inhabitant }\end{array}$ \\
\hline $\begin{array}{l}\text { Riga (except Riga city, } \\
\text { Jurmala city, and Riga } \\
\text { district)* }\end{array}$ & 2875424 & $10 \%$ & - & - \\
\hline $\begin{array}{l}\text { Creative industries BI in } \\
\text { Riga city* }\end{array}$ & 2875424 & $10 \%$ & - & - \\
\hline Vidzeme & 5750849 & $20 \%$ & 224147 & 25.65 \\
\hline Latgale & 5750849 & $20 \%$ & 323016 & 17.80 \\
\hline Zemgale & 5750849 & $20 \%$ & 267725 & 21.49 \\
\hline Kurzeme & 5750849 & $20 \%$ & 285968 & 20.11 \\
\hline
\end{tabular}

*Due to the specific information, it is not possible to identify and calculate the number of population and the funding per inhabitant at the territory of Riga Planning Region and the territory of the creative industries BI.

Within the activity, until 31 December 2013, 493 companies had been exincubated. During this period of time, the Ministry of Economics discovered the tendency pointing out the increasing number of liquidated companies and companies under the insolvency procedures. Evaluating the enterprises from the moment the financial aid was received, it was identified that the funding had provided the necessary impetus to launch the economic activity.

Only enterprises that had submitted the annual report were evaluated as the operating enterprises. There is a detectable trend (See: Figure 1) that the public support allows $90 \%$ of companies to start up the economic activities and provides them an opportunity to stabilize in the business environment for the first two years, whereas the number of companies that are able to withstand the competition tends to decrease in the fourth year of operation. According to the 
Iluta Arbidāne, Madara Tarasova. Analysis and Development Possibilities of Business Incubators in Latvia

Initial Evaluation by the Ministry of Economics (2015), only 17\% of the enterprises continued their economic activities five years after the moment the public support had been received.

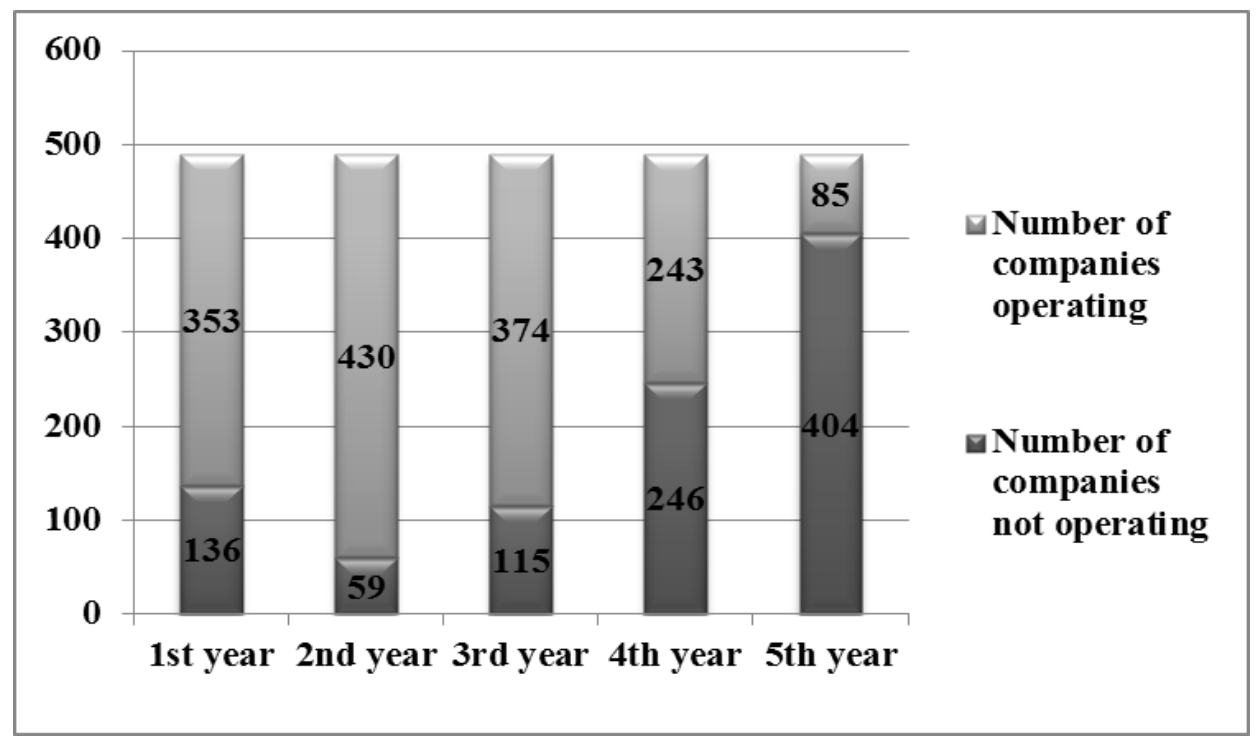

Figure 1 Number of companies operating after ex-incubation

(Initial Evaluation by the Ministry of Economics, 2015)

The number of employees of a company is one of the activity indicators to receive de minimis aid. Five years after the public support had been received, the economic activities were carried out by those companies that were able to grow, to find customers for the services/products, and to win the market share. The increased number of employees is also an evidence for the development of these companies (Figure 2).

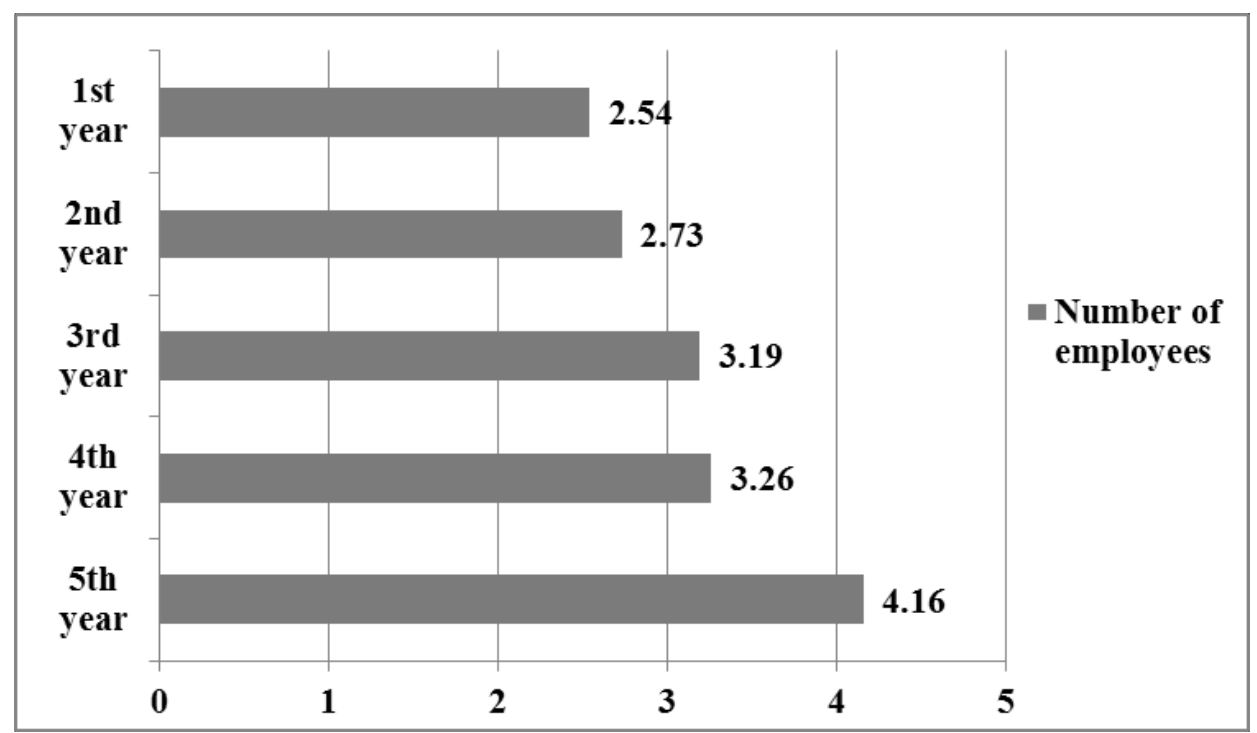

Figure 2 Average number of employees in companies after ex-incubation (Initial Evaluation by the Ministry of Economics, 2015) 
Data (Figure 2) suggest that, in the first year of development, the number of employees is 2.5 persons in average, whereas after five years the average number of employees increases to 4.2. That has to be assessed as a positive result, since of the number of jobs has increased.

Table 2 BI performance indicators in planning regions, 2009-2013

(compiled by the authors)

\begin{tabular}{|l|l|l|l|l|l|}
\hline \multicolumn{1}{|c|}{ Planning region } & $\begin{array}{c}\text { Number of } \\
\text { enterprises }\end{array}$ & $\begin{array}{c}\text { Turnover, } \\
\text { million } \\
\text { EUR }\end{array}$ & $\begin{array}{c}\text { Volume of } \\
\text { exports, } \\
\text { million } \\
\text { EUR }\end{array}$ & $\begin{array}{c}\text { Volume of } \\
\text { taxes } \\
\text { paid, } \\
\text { million } \\
\text { EUR }\end{array}$ & $\begin{array}{c}\text { de minimis } \\
\text { aid provided } \\
\text { by BI, } \\
\text { million } \\
\text { EUR }\end{array}$ \\
\hline $\begin{array}{l}\text { Riga (except Riga } \\
\text { city, Jurmala city, } \\
\text { and Riga district)* }\end{array}$ & 119 & 11.31 & 2.05 & 1.49 & 1.11 \\
\hline $\begin{array}{l}\text { Creative industries } \\
\text { BI in Riga city* }\end{array}$ & 117 & 9.46 & 0.78 & 1.05 & 1.65 \\
\hline Vidzeme & 212 & 15.08 & 4.43 & 1.71 & 2.82 \\
\hline Latgale & 150 & 14.93 & 5.86 & 1.11 & 1.47 \\
\hline Zemgale & 135 & 43.58 & 9.6 & 3.74 & 2.63 \\
\hline Kurzeme & 225 & 45.18 & 8.08 & 5.09 & 3.76 \\
\hline TOTAL & $\mathbf{9 5 8}$ & $\mathbf{1 3 9 . 5 4}$ & $\mathbf{3 0 . 8}$ & $\mathbf{1 4 . 1 9}$ & $\mathbf{1 3 . 4 4}$ \\
\hline
\end{tabular}

The total number of the enterprises in the BI since the start of operations has reached 958 entrepreneurs (unprocessed data of the period 2014-2015 is not taken into account). Within all the period of BI operation, the largest number of businesses is marked in Kurzeme and Vidzeme planning regions. Each territory that is overseen by a particular BI operator has its own distinctiveness that influences both the number of companies at the BI, and business activity in general. These factors are, for instance, the proximity of universities and higher education establishments, industry traditions, infrastructure, geographic location, mentality of population. Assessment of the turnover and export indicators show the best statistics in Kurzeme and Zemgale regions, where, while funding the enterprises, a substantial emphasis was placed on the companies' ability to export their products and, thus, to expand their activities, to raise product awareness, to increase production volumes. Accordingly, these regions have also the best collected taxes indicators that correlate with the turnover values. 


\section{Opportunities for business incubators in Latvia in programming period 2014 - 2020}

In the programming period 2007-2013, the incubators provided incubation services, administered granting the public support, and performed administrative functions. At the event „Regional business incubators and creative industries incubator" of the programming period 2014-2020, the LIAA took over the state aid functions. Further on, services to the incubated companies will be provided by the economic operators, including existing BI operators. The project applicant is the LIAA which, in accordance with a function specified in the regulations (to enhance establishment and development of businesses), will provide support to the enterprises and will promote regional cooperation. As a beneficiary, the LIAA with the local governments, businesses organizations, and regional universities will agree on the specific settings for the incubation support.

The support programme is envisaged to support all phases of incubation. The incubation support includes three phases:

- $\quad$ Pre-incubation - for individuals, newly-established businesses;

- Incubation support - for start-up entrepreneurs;

- After-incubation - for sustainable businesses that need business development, international cooperation, networking.

In order to enhance the impact of the measures of the programming period 2014-2020, there has been set a criterion, stipulating that the municipalities and $\mathrm{BI}$ have to establish a required relationship between the BI enterprise and the municipality. It can be specified by the municipality stating that all or part of BI enterprises have to perform their economic activities in the region, or they have to be legally registered in the region, or have any other agreed relationship with the region. This is a positive condition, which could enhance the selfemployment potential in the region, create new jobs, and boost regional development. Consequently, the local self-governments are more interested in supporting entrepreneurship and implementation of its objectives in particular areas.

Achievement of certain indicators is possible in the regions and the countries with well-developed business experience. Analysing the results of the previous period, it can be concluded that the entrepreneurs had difficulties to maintain stable development indicators and to avoid the liquidation proceedings. In the next programming period, taking into account the experience obtained in the planning regions of Latvia, it would be useful to identify and to assess not only quantitative indicators, but also to evaluate each company's ability to provide and develop the following: 
- to increase the number of employees, including the number of employees in the newly established enterprises;

- $\quad$ to provide a minimum salary and increase an average one;

- to increase turnover, export capacity, and profit;

- to consider taxability and increase volume of paid taxes (Initial Evaluation by the Ministry of Economics, 2015).

In the programming period 2014-2020, the support is focused on providing pre-incubation and incubation services for the entrepreneurs; though the biggest problem of the start-ups is the ability to raise funds for business or idea development. In addition to the necessary financial support, the new businesses need a competent consultative support. Taking into account the previous experience, the use of funding would be much more valuable if the emphasis was placed on creation of innovative products with added value rather than on the increase of the number of enterprises.

\section{Conclusions}

The business incubators (BI) are a relatively new instrument in Latvia that was launched in 2007 by implementing programmes for the development of innovation centres and business incubators. The insufficient number of viable, competitive and economically active enterprises that enhance the economic growth and provide a sufficient number of jobs could be mentioned as the main reason for establishing business incubators.

Currently, the BIs represent a kind of support to the entrepreneurs both in starting up business, expanding the company's operations, implementing innovation, and in commercializing innovation in the market. The main functions of BI are to enhance the establishment of new companies, offering the up-to-date information on legislation and other topics, consulting on marketing, management, financial management, accounting, and other issues important for the entrepreneur's activity.

In the previous programming period, the public funding was distributed equally among all planning regions, regardless of their peculiarities and specific factors, such as the number of population, the rate of unemployment, level of economic growth, business activity in general, accessibility of infrastructure, cooperation with universities, etc. The results of the programme implementation have pointed out significant differences between the regions. The best growth potential was demonstrated by the regions, where the incubated businesses had been selected evaluating their capacity for the export and possibilities to increase turnover. In the new programming period, it is envisaged to establish a stronger link between the local self-governments and business incubators. That should be evaluated as a positive aspect which would allow enhancing the self- 
Iluta Arbidāne, Madara Tarasova. Analysis and Development Possibilities of Business Incubators in Latvia

employment potential, creating new jobs, and developing business environment in the region. The use of the funding would be more effective if the emphasis was placed on the support to the companies which are able to create and develop innovative products with high added value rather than focusing on increasing the number of the companies which can sometimes be observed in practice.

\section{References}

3.1.1.specifiskā atbalsta mērķa „Sekmēt MVK izveidi un attīstîbu, īpaši apstrādes rūpniecībā un RIS3 prioritārajās nozarēs" 3.1.1.6.pasākuma "Reǵionālie biznesa inkubatori un radošo industriju inkubators", sākotnējais novêrtējums, 1.daḷa "Reǵionālie biznesa inkubatori un vispārīgi inkubatoru jautājumi” (2015). LR Ekonomikas Ministrija: Rīga, p.51.

Ābeltiņa, A. (2008). Inovācija-XX gadsimta fenomens. Rīga: Biznesa augstskola "Turība", 117.

Jennings, P., \& Beaver, G. (1997). The Performance and Competitive Advantage of Small Firms: A Management Perspective, International Small Business Journal, 63-75.

JOIN US, [online]. [cited Januar 23, 2015]. Downloaded from: http://www.ebn.eu/ index.php?lnk=KzF0aDVES1I3bG9TYXFGeEhLL2dQNkRQVWFKNTNWRjQ0a0tz N24vRFUOST0

Kassalis, I. (2010). Uzṇēmumu konkurētspējas paaugstināšanas iespējas Latvijas tautsaimniecībā. Latvijas Universitātes raksti. 754. sēj.: Ekonomika un Vadības zinātne, 9. - 22. Downloaded from: http://www.lu.lv/fileadmin/user_upload/ lu_portal/apgads/PDF/LUR-754_Ekonomika.pdf

Latvijas Investīciju un Attīstības Aǵentūra. (2007). Inovatīvās darbības pamatelementi. Rīga: Latvijas Investīiju un attīstības aǵentūra. 276.

Macdonald, M, S., Assimakopoulos, A.D., \& Anderson, P. (2007). Education and Training for Innovation in SMEs: A Tale of Exploitation, International Small Business Journal,Vol. 25 (1), 77-95.

Markus, K. (2010). Biznesa inkubatori Latvijā - efektīvs uzṇēmējdarbības atbalsta instruments. Latvijas Universitātes raksti. 754. sēj.: Ekonomika un Vadības zinātne, 167. -176 .

Noteikumi par darbības programmas "Uzñēmējdarbība un inovācijas" papildinājuma 2.3.2.1.aktivitāti "Biznesa inkubatori". (2008., 29.okt.). Ministru kabineta noteikumi Nr.835. Downloaded from: http://likumi.lv/doc.php?id=183034

Number of Business Incubator Worldwide [online]. [cited May 27, 2015]. Downloaded from: http://worldbusinessincubation.files.wordpress.com/2013/03/number-of-businessincubators-worldwide.png

Pagarināts biznesa inkubatoru atbalsta programmas darbības terminšs. Downloaded from: https://www.em.gov.lv/lv/jaunumi/7140-pagarinats-biznesa-inkubatoru-atbalstaprogrammas-darbibas-termins

Stonehous, G., \& Snowdon, B. (2007). Competitive Advantage Revisited: Michael Porter on Strategy and Competitiveness. Journal of Management Inquiry, Vol. 16 (3), 256-273.

Todtling, F., \& Kaufman, A. (2001). The Role of the Region for Innovation Activities of SMEs. European Urban and Regional Studies, 203-215.

Wang, Y., \& Costello, P. (2009). An Investigation into Innovations in SMEs: Evidence from the West Midlands, Uk. Journal of Entrepreneurship,18, 1, 65-93. 